\title{
Comparative study of scientific literacy: Indonesian and Thai pre-service science teachers report
}

\author{
R. Ahmad Zaky El Islami' ${ }^{1}$, Prasart Nuangchalerm² \\ ${ }^{1}$ Department of Science Education, Universitas Sultan Ageng Tirtayasa, Indonesia \\ ${ }^{2}$ Department of Curriculum and Instruction, Mahasarakham University, Thailand
}

\section{Article Info \\ Article history: \\ Received Oct 8, 2019 \\ Revised Mar 22, 2020 \\ Accepted Apr 28, 2020 \\ Keywords: \\ Baduy's society \\ Local wisdom \\ Science education \\ Science literacy \\ Teacher education}

\begin{abstract}
The changing world needs literate citizens to live with creative society. This study aimed to compare science literacy of novice science teacher students from Thailand and Indonesia. Panel participants were 95 of Thai and 71 of Indonesian novice science teacher students who have been studying in the $1^{\text {st }}$ and $2^{\text {nd }}$ year of study in bachelor degree of science education programme. Data were collected by employed science literacy inventory; it was used for asking four components: content of science, context of science, science process, and scientific attitude based on local wisdom of Baduy's society. Participants are freely considered in their perception. Results showed that Thai novice science teacher students had slightly better score than those Indonesian novice science teacher students, but statistical testing is not showed the differences. The future study is required to more investigation of how they promote science literacy in their school practicum.
\end{abstract}

This is an open access article under the CC BY-SA license.

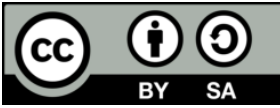

\section{Corresponding Author:}

R. Ahmad Zaky El Islami,

Department of Science Education,

Faculty of Teacher Training and Education,

Universitas Sultan Ageng Tirtayasa,

Ciwaru Raya No. 25 Street, Cipocok Jaya, Serang, Banten, Indonesia.

Email: zakyislami@untirta.ac.id

\section{INTRODUCTION}

Science literacy is termed that often used but seldom defined [1]. It is widely used in field of study in science education, a broad concept encompassing in educational themes that have shifted over time [2]. Science literacy is knowledge and understanding in science and process of science in which required personal decision making, cultures participation, and science attitudes [3]. Citizens have to learn and understand what science is and how science works. Science literacy helps person able to ask, make inquiring questions determining answers derived from curiosity about everyday experiences Also, person can describe, explain, predict, investigate, and discuss about natural phenomena [4]. That is, science literacy is necessary for all citizen, not only knowledge, but science in daily and its useful are also considered. It bridges person to scientific issues and culture by expressing positions to public information. The quality of scientific information on the basis of its source and the methods used to generate it can be evaluated by literate person $[2,5,6]$.

Science literacy leads person to literate science and culture in which occurred in our society. Citizen can express attitudes toward science in positively, it helps person know and understand of what science should be, and also motivate person to have critical thinking and argumentation with natural phenomena [7, 8]. If citizen lack of literacy may be culture of science decreases and influence to the advancement of science [9]. While as teacher is a key agent to incorporate science literacy into classroom 
and promote science literacy to young children and youths. According to educational policy, making learning society by employing science to life and career has to do as well as other contents. Society also needs science to their real life situations for argumentation and promoting science to development at all. Teacher can embed science to students and lead to quality of citizen. The programme for teacher preparation be able to incubate science literacy and nature of science as well [10]. Then, literate teachers can promote education through science. Science and society will be met the requirements of science education for all. The scientific literacy in Program for International Student Assessment (PISA) divided in four domains, such as content of science, context of science/competence, science process and science attitude [11]. The previous studies to compare components of scientific literacy between Indonesian and Thai pre-service science teachers such as context of science, content of science and science process have been conducted. Nuangchalerm and El Islami [12] surveyed the context of science of Indonesian and Thai novice science teacher students, the results showed there was no statistically significant between Thai and Indonesian. Nuangchalerm and El Islami [13] surveyed the content of science of Indonesian and Thai novice science teacher students, the results showed there was no statistically significant between Thai and Indonesian. El Islami et al [14] surveyed the science process of Indonesian and Thai novice science teacher students, the results showed that Thai science teacher candidates had mean score higher than those Indonesian science teacher candidates at 0.05 level of statistics. However, these three studies about component of scientific literacy only concern in each component not compare the scientific literacy as a unity, so this research must be conducted to know the comparison of scientific literacy between Indonesian and Thai novice science teacher students. In PISA 2000 , the average of scientific literacy of Thai students was at $32^{\text {th }}$ ranking and Indonesian students was at $39^{\text {th }}$ rangking [15]. In PISA 2003, the average of scientific literacy of Thai students was at $36^{\text {th }}$ ranking and Indonesian students was at $38^{\text {th }}$ ranking [16]. In PISA 2006, the average of scientific literacy of Thai students was at $44^{\text {th }}$ ranking and Indonesian students was at $50^{\text {th }}$ ranking [11]. In PISA 2009, the average of scientific literacy of Thai students was at $49^{\text {th }}$ ranking and Indonesia was at $62^{\text {th }}$ ranking [17]. In PISA 2012, the average of scientific literacy of Thai students was at $44^{\text {th }}$ position and Indonesian students was at $63^{\text {th }}$ rangking [18]. In PISA 2015, the average of scientific literacy of Thai students was at $44^{\text {th }}$ position and Indonesian students was in $62^{\text {th }}$ ranking [19]. The survey results of PISA 2000-2015 on scientific literacy of Thai and Indonesian studnets can be shown in Figure 1. Based on PISA Results since year 2000 until 2015 , can be concluded that the Thai students' scientific literacy always better than Indonesian students. However, this survey were conducted in the school level, so we must conducted the survey in university level such as in the context of Indonesian and Thai novice science teacher students.

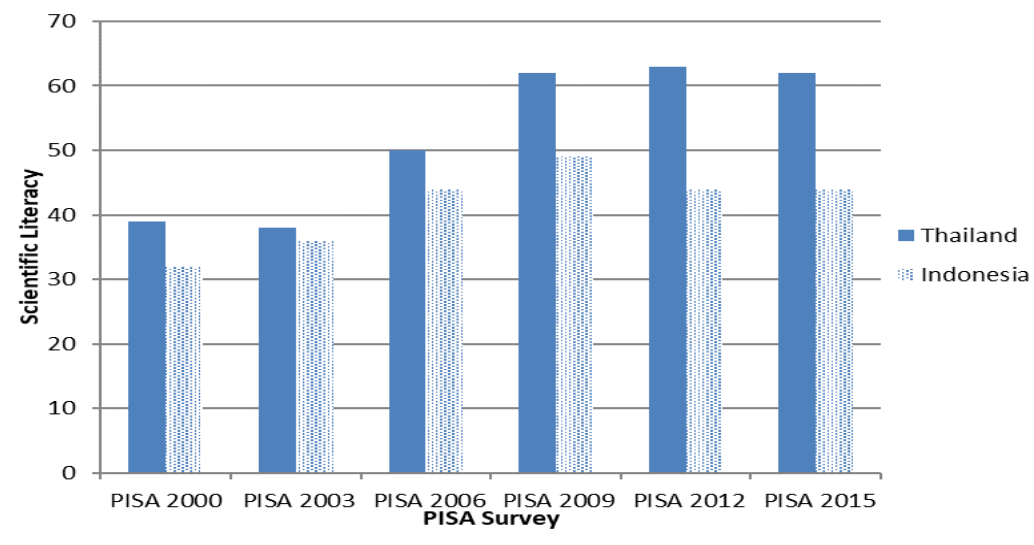

Figure 1. PISA results of Thai and Indonesian students' scientific literacy average during 2000-2015

Science is a culture of humanity in harmoniously and guiding the direction of social development [20]. It is very difficult to separate science and culture from our community because it is co-evolution in different contexts. The elderly can transfer some useful knowledge to the next generation by no means of scientific explanation, but it links culture and science together. Process of science is not only investigating new knowledge to explain phenomena, but it should be related to our lives. Science education purposes to establish learning and teaching through science literacy in our society as well [21]. It can be propagated by creative problem solving for in the way of embedding personal and social growths [22]. It can be considered that science literacy contains the knowledge and understanding of scientific concepts

Int. J. Eval. \& Res. Educ. Vol. 9, No. 2, June 2020: 261 - 268 
and inquiry process that making decision, social, cultural, and economical products [23]. We can consider that science literacy allows someone to have science literacy covering its scientific knowledge, science process skills, and science attitude.

Science is not only subject matter, but it is a process of knowledge construction. Science can explain of what scientific knowledge should be, setting hypothesis and identify problem, conduct a reliable method to study, and draw a conclusion based on testable evidences. Laugksch [24] proposed that science literacy is very important for science education. It can distribute scientific ways to society. Curriculum and instructional practices have to implement science literacy to school science as well as making literate person for social development. Person is eligible to solve problems and make decision to solve problems by using scientific concepts. Science literacy should matter to all citizens because it shapes them think and do as scientists. It enables people to weigh options and makes the decision of information as individuals and as citizens of a democracy. When experienced as cultural and aesthetic enrichment, it can promote better stewardship of the science education. Based on focusing inquiry-based learning, socioscientific issues-based learning, and various methods of learning to science instruction, it can promote science literacy to all [25].

Our society is now facing with rapidly distributed of knowledge and new exploration. That's why all need science literacy in education, the process of education helps learners transforming more than scientific knowledge. Science teachers are change agent to science education, literate science, and reforming education. Teachers in this era need to prepare for a changing world by connecting science to real world and cultural changes [26-29]. We cannot reject that teacher is key agent to bring science literacy that allows citizen to describe science in terms of knowledge, skills, and attitudes. Teacher can transfer scientific knowledge to classroom, but process of science and science literacy can implement in a variety of methods of teaching. Students should retain knowledge and understanding in the phenomenon surroundings them through their learning experience [4]. It offered a series of recommendations for reforming our system in the relation to holistic science.

DeBoer [2] pointed that science literacy emerged from the i) teaching sciences and learning sciences as a cultural force in the modern era, ii) preparing to face the world of work, iii) teaching sciences and learning sciences with everyday living context, iv) teaching students to be informed citizens, v) learning sciences as a particular way of examining the natural world, vi) understanding reports and discussions of science that appear in the popular media, vii) learning sciences for its aesthetic appeal, viii) preparing citizens who are sympathetic to science, and iv) understanding the nature and importance of technology and the relationship between technology and science. We cannot claim that unexplainable natural phenomenon by process of science. Due to science needs evidence and explanation to citizen in clearly based on science literacy as a foundation [30]. Preparing a professional teacher need to look quality of teacher students who introduce disciplines into classroom. They have to perceive and bring science to classroom as well as its nature.

Science literacy describes the learning science through strategies, goals of science, content, and processes of science embedded in education. Teacher education in part of science teacher students have process of development, is initial point of teacher development. Literate teacher students will create learning person and do as scientists in the future. If they had high or premium quality, we can predict the quality of society in the future. Based on previous studies there is no research to compare science literacy between Indonesian and Thai novice science teacher students, so this research is very important and new. This study aims to compare novice science teachers in science education programme between Thailand and Indonesia. The findings will help educators to promote scientific literacy to students and preparing students to have learning society in their learning behaviors.

\section{RESEARCH METHOD}

This study employed comparative information from novice science teacher students. Ninety-five, enrolled in $1^{\text {st }}$ and $2^{\text {nd }}$ year of bachelor programme in science education from Mahasarakham University, Thailand. Novice science teacher students of 71 Indonesian are also gathered data from Universitas Sultan Ageng Tirtayasa, Indonesia. These two universities are a public university in each country, so we can collect the data from these two universities. The framework of scientific literacy in this study was adopted from PISA 2006, because in PISA 2016 was more focus on science [11]. Science literacy in this study is measured through science literacy inventory adopted from [31]. It is 4-multiple choice for evaluating 4 domains of science literacy; content of science, context of science, science process, and science attitude. Three situations with 9 questions let participants' concern local science, Baduy's society and their traditions of living. The grating of science literacy instrument used is given in Table 1. 
Table 1. Components of science literacy [3]

\begin{tabular}{cc}
\hline Domain of science literacy & Indicator \\
\hline & Nature of light \\
The benefits of light \\
Content of science & The impact of artificial chemicals \\
& Nature of air \\
Air circulation \\
Baduy house position \\
Context of science & Use of natural chemicals \\
& Baduy tribe house form \\
Science Process & Identify scientific issues \\
& Explain the scientific phenomenon \\
& Using scientific evidence \\
Scientific Attitude & Responsibility \\
& Supports scientific inquiry \\
\hline
\end{tabular}

This study collected data in January-February 2018 in each university. The science literacy inventory was given to teacher students who are studying in the $1^{\text {st }}$ and $2^{\text {nd }}$ year of study. Even though different community, but Thai students are concerned with local wisdom and make their conception about phenomena. Then, they have to express their perception in terms of scientific explanation. Data is gathered by introducing local knowledge of Baduy's society and their traditions; later, panel participants' response to each component of science literacy by themselves. They have freely respond in each items, no more explanation before complete questionnaires. Data is collected by surveying from two countries in the same period of study and then researchers have a checking the completeness in respondents. Mann-Whitney U test are employed for testing the hypothesis and answering objectives of study. Findings are presented in descriptive analysis and statistical testing. To know the difference of science literacy between Thai and Indonesian novice science teacher students we have calculated both of the average of science literacy score and compare it, then used the Mann-Whitney $U$ test to know the significancy of differences of science literacy average between Thai and Indonesian [32].

\section{RESULTS AND DISCUSSION}

The aspects of science literacy are; content of science, context of science, science process and science attitude are investigated. Finding indicated that novice science teachers had science literacy. This research conducted at one of the state universities from Indonesia and one of the state universities from Thailand. By the exploration, Thai novice science teachers had mean higher then Indonesian novice science teachers. The descriptive and non-parametric statistics can be shown in Table 2.

Table 2. Recap overall science literacy

\begin{tabular}{ccc}
\hline Thai (Mean) & Indonesian (Mean) & Mann-Whitney U test $(\alpha)$ \\
\hline 52 & 47 & $0.087>0.05$ \\
\hline
\end{tabular}

We can see on Table 2 that the science literacy of Thai had score slightly better than Indonesian, although is not statistically differences (Sig. 0.087). It is not a distinction report to claim that Thai pre-service teachers had scientific literacy in which science education standard requires. It needs to have more study in large cohorts of participants. However, this result confirmed by the report of the last PISA survey in 2015 revealed that the science literacy of Thailand's student in $54^{\text {th }}$ position and Indonesia in $62^{\text {th }}$ position from 71 countries [19]. Thailand and Indonesia located in Southeast Asia, both of them include in ASEAN (Association of Southeast Asian Nations) and the culture of learning and also science education seems to be co-evolution curriculum. As we know, SEAMEO and partnership of ASEAN deals with culture of learning, local wisdom-based study, community-based science education, and policy towards education. Thailand has difference system with Indonesia in education programme, but the culture of learning calls for local science or linking local science to global science. PISA holds standards of education and educational testing through learning environments, necessary contents, culture of learning, and ways of promoting science based on contexts of developed countries. While Thailand and Indonesia try to learn and develop our educational system, we cannot deny local culture and science to our curriculum.

Teacher preparation programme in Thailand and Indonesia can be considered by duration time of study. Teacher education programme in Thailand conducts 4 years for theoretical university with 1 year for 
school practicum, but Indonesian pre-service teachers include university classroom and practicum in school for 4 years. It can give the difference output of pre-service teacher especially for science teachers. Moreover, Thailand launched the professional standards for pre-service teachers to gain their knowledge, ability, competency, and attributes to prepare professional teachers [33]. It means that they have extension time for incubating characteristics of teachers. They also have to learn condensed contents and science process skills as well as science students do. It can support this research output that the science literacy of Thai slightly better than Indonesian.

Many previous studies from Indonesian scholars as efforts to develop science literacy of Indonesian students or teacher students, Saefullah et al [34] conducted in university level by included the local wisdom of Baduy tribe in the guided inquiry learning model society oriented science literacy, this research concluded that there was an improvement in students' science literacy after guided inquiry learning was applied as shown with $\mathrm{N}$-Gain $=0.16$ which was included in the low category. As we known a local science can engage students to learn science, but a universal knowledge or conceptual understanding towards science need to be promoted in the teacher preparation programme. Moreover, El Islami et al [35] implemented the inquiry learning model in school to improve the science literacy, in this study found there was no significant difference between the experimental group and control group students in the average of science literacy. The science literacy might want to promote inquiry-based learning, science and society concerns, socioscientific issues-based instruction, and embedding nature of science to science teacher preparation programme.

Accordingly, Rakhmawan et al [36] developed the inquiry learning based laboratory activity oriented science literacy skills of high school student in a voltaic cell lesson as the efforts from Indonesian researchers to develop scientific literacy of Indonesian students. That is, scientific literacy is not only content or process of science, but also nature of science and learning culture help them to meet the goals of science education which scientific literacy relied. Nuangchalerm [8] reported that science education teachers had nature of science and socioscientific issues, which related to science literacy. If they lack of these it tends to be student less science literacy. It is significant domain in science teachers should understand. Also, citizen should be literate in science through education and education through science. The world of science is now rapidly changed by the revolution of information technology or internet boom. Scientific literacy is not concern only of what students know but they have to critique information and allow process of science to investigate the physical and biological worlds surrounding to them.

Finally, there is no significant difference between Thai and Indonesian novice science teacher students in science literacy. It is a preliminary study in developing the science education. Learning paradigm needs changing in mindset of novice science teacher students in science literacy need to be improved. Not only Thailand and Indonesian are now seeking the alternative ways up rising quality of science education, but all countries in the world. Fakhriyah, et al. [37] studied science literacy of Indonesian teacher students, results showed that science literacy skills of primary teacher education students had a concept for connecting science with other disciplines in the nominal level. They are mostly still misconceptions, whereas some of them $(33.8 \%)$ understand scientific theory and can explain scientific concepts in correctly. They had narrow understanding and unable to explain concept. According to Handayani [38], argues that the implication of science literacy affects person ability to make correlation between science issues in which personal opinions, local-based knowledge to survive, and decision making. Science literacy can be described in the local-global knowledge that depends on perception.

Cultural aspects may be made literacy to be different as it above. Indonesian and Thai teacher students in the mode of science literacy through curriculum and its implementation need to be explored [13, 30]. Curriculum and pedagogy should be emphasized in such necessary skills for teacher preparation. However, the study need to be monitored because it can be changed depends on policy and programme of education. It can indicate to quality of education, helps science educators to seek the alternative procedure to promote science literacy to all. However, the transforming era is now adapting by universal science and local science need explicit explanation, meet the sense of science, provable to public, and do contemporary understanding [39].

Thai novice science teacher students had better than Indonesian novice science teacher students. Due to the curriculum and teaching strategies which professional standards and science teacher standard defined their competency and attributes. They have to express not only knowledge, but also the process of curriculum implementation and teaching strategies are designed. Yuenyong and Narjaikaew [40] explained that Thailand science education implement the cases local wisdom in the learning to develop students' science literacy. It is way of life and way of learning science through traditional science. The local wisdom which used in science learning especially King Bhumibol Aduladej's philosophy of suffuciency econimu, moral infusion, and the way of eastern life. Sofiani et al [41] explained that Indonesian students have positive attitude towards science in medium level. It can be explained that most of Indonesian students were 
confident with their performance in science, but they have not high motivation to explore more information about science.

Accordingly, Saefullah et al [34] implemented the local wisdom of Baduy's society in learning of science in one of university in Indonesia through guided inquiry learning but the improvement of scientific literacy with this treatment is still low. Indonesia government needs to make the best treatment to develop science for novice science teacher students. In fact, Indonesia has implemented the new curriculum namely "curriculum 2013", in this curriculum integrating daily phenomena in learning, but the implementation of curriculum 2013 is not effective yet. Science is needed to promote for young citizens by the readiness of teachers and schools in implementing the curriculum 2013, the availability of infrastructur facilities is sufficient, but teachers still had difficulties in making learning tools and managing the clasroom with using scientific approach [42]. Science for our children can be improved, teacher take science literacy into account of local wisdom and nature of learning, and the development of teaching strategies in accordance with suitable learning environment [43].

Especially, the new era of learning, young students can access internet for taking knowledge around the world. They can see and understand of what science think and do through online learning, social media, and social networking. The culture of learning is changed, novice science teachers must prepare themselves based on process of science, world view to science, and allow science literacy to modern classroom. However, different countries, different contexts, but science can explain itself as well as reliable methods. The teacher preparation programme should invite affective learning much more than cognitive learning. Thai and Indonesian teacher education must concern how to produce science teachers to understand nature of science. Also, bridging the gap between local culture and modern science into classroom is the way to make a simply science literacy.

\section{CONCLUSION}

The science literacy of Thai novice science teacher students had slightly better score than those Indonesian novice science teacher students, but there is no significantly difference between Thai and Indonesian novice science teacher students in science literacy statistically. Findings can be discuss about teacher preparation programme. Thai novice science teachers had course of core subject in sciences by early year of study. They have to implement professional standards of teachers in the $4^{\text {th }}$ or $5^{\text {th }}$ year in the programme of study. However, local science is still need to be learned as well as modern science. In terms of inherited local wisdom, the participants learned it directly through their own experiences and indirectly from their ancestors. Scientific explanation requires to new cohorts and also generalizes to modern life. It was highly integrated and linked to people's ways of life. Differently, local wisdom emerges from spiritual factors and let them to survive with nature in friendly. People can live with other organism and environments based on balance of life than those capital markets. Modern science can create and invent technology for serving our life, but it easy to describe in terms of live with physical environments while as spiritual is intrinsic component of livings. Science literacy can make a linkage between local science and modern science through science in daily lives. It is not separated from our society, but it is a necessary process of thinking and doing.

Mean score cannot be indicated that Thai novice science teacher had better curriculum or teaching strategy because Thai and Indonesian science education had different contexts. We prepare our novice science teacher through education policy, and professional standards based on expected learning outcomes. The well-designed curriculum and instruction in teacher preparation need to implement science literacy for preparing $21^{\text {st }}$ century science teachers such as use and develop innovative learning through STEM Education as integrated learning approach to improve scientific literacy. The future study is required to more investigation of how they promote science literacy in their school practicum. It can connect how science teacher students employ science literacy into their classroom and school activities. They are key factors to increase our young citizens to reach the goals of science education, and also learn to make competitive collaboration in world of changes.

\section{ACKNOWLEDGEMENTS}

The authors are sincerely expressed to the Faculty of Education, Mahasarakham University, Thailand and the Faculty of Teacher Training and Education, Universitas Sultan Ageng Tirtayasa, Indonesia for allowing us to conduct research collaboration. 


\section{REFERENCES}

[1] J. D. Miller, "Scientific literacy: A conceptual and empirical review," Daedalus, pp. 29-48, 1983.

[2] G. E. DeBoer, "Scientific literacy: Another look at its historical and contemporary meanings and its relationship to science education reform," Journal of Research in Science Teaching, vol. 37, no. 6, pp. 582-601, 2000.

[3] National Research Council (NRC), National science education standards. National Academies Press, 1996.

[4] American Association for the Advancement of Science (AAAS), Benchmarks for science literacy. Oxford University Press, 1994.

[5] R. Millar, "Twenty first century science: Insights from the design and implementation of a scientific literacy approach in school science," International Journal of Science Education, vol. 28, no. 13, pp. 1499-1521, 2006.

[6] R. T. Muskania and I. Wilujeng, "Development of project-based learning tools for equipping foundational knowledge and enhancing scientific literacy (in Bahasa)," Cakrawala Pendidikan, vol. 35, no.1, pp. 34-43, 2017.

[7] S. D. Kolstø, "Scientific literacy for citizenship: Tools for dealing with the science dimension of controversial socioscientific issues," Science Education, vol. 85, no. 3, pp. 291-310, 2001.

[8] P. Nuangchalerm, "Engaging students to perceive nature of science through socioscientific issues-based instruction," European Journal of Social Sciences, vol. 13, no. 1, pp. 34-37, 2010.

[9] J. Holbrook and M. Rannikmae, "The nature of science education for enhancing scientific literacy," International Journal of Science Education, vol. 29, no. 11, pp. 1347-1362, 2007.

[10] P. Wongsri and P. Nuangchalerm, "Learning outcomes between socioscientific issues-based learning and conventional learning activities," Journal of Social Sciences, vol. 6, no. 2, pp. 240-243, 2010.

[11] OECD, Executive summary PISA 2006: Science competencies for tomorrow's world. OECD Publishing, ParisFrance, 2007.

[12] P. Nuangchalerm and R.A.Z. El Islami, "Context of science on environmental conservation: Comparative study between Thai and Indonesian novice science teacher students," Jurnal Penelitian dan Pembelajaran IPA, vol. 4, no. 1, pp. 60-67, 2018a.

[13] P. Nuangchalerm and R.A.Z. El Islami, "Comparative study between Indonesian and Thai novice science teacher students in content of science," Journal for the Education of Gifted Young Scientists, vol. 6, no. 2, pp. 23-29, 2018.

[14] R.A.Z. El Islami, et al., "Science process of environmental conservation: A cross national study of Thai and Indonesian pre-service science teachers," Journal for the Education of Gifted Young Scientists, vol. 6, no. 4, pp. 72-80, 2018.

[15] OECD, Knowledge and skills for life first result from PISA 2000. OECD Publishing, Paris-France, 2001.

[16] OECD, Learning for tomorrow's world first result from PISA 2003. OECD Publishing, Paris-France, 2004.

[17] OECD, PISA 2009 results: What students know and can do-Student performance in reading, mathematics and science (Volume I). OECD Publishing, Paris-France, 2010.

[18] OECD, PISA 2012 results: What students know and can do-Student performance in reading, mathematics and science (Volume I). OECD Publishing, Paris-France, 2014.

[19] OECD, PISA 2015 results in focus. OECD Publishing, Paris-France, 2018.

[20] Y. Kusmarni and M. Holilah., "The ecological wisdom values of agricultural land utilization by the indigenous people of Cigugur Kuningan, West Java," IOP Conference Series: Earth and Environmental Science, vol. 145, no. $1,2018$.

[21] S.P. Norris and L.M. Philips, "How literacy in its fundamental sense is central to scientific literacy," Science Education, vol. 7, no.2, pp. 224-240, 2003.

[22] N.G. Lederman, et al., "Nature of science and scientific inquiry as contexts for the learning of science and achievement of scientific literacy," International Journal of Education in Mathematics, Science and Technology, vol. 1, no. 3, pp. 138-147, 2013.

[23] D. Dani, "Scientific literacy and purposes for teaching science: A case study of Lebanese private school teachers," International Journal of Environmental and Science Education, vol. 4, no. 3, pp. 289-299, 2009.

[24] R. C. Laugksch, "Scientific literacy: A conceptual overview," Science Education, vol. 84, no. 1, pp. 71-94, 2000.

[25] Gormally, et al., "Effects of inquiry-based learning on students' science literacy skills and confidence," International Journal for the Scholarship of Teaching and Learning, vol. 3, no. 2, pp. 1-22, 2009.

[26] L. Darling-Hammond, "Teacher quality and student achievement," Education Policy Analysis Archives, vol. 8, no. $1,2000$.

[27] L. Darling-Hammond and J. Bransford, (Eds.), Preparing teachers for a changing world: What teachers should learn and be able to do. John Wiley \& Sons, 2007.

[28] H.M. Affandi, et al., "Knowledge, attitude and awareness towards research practice among Malaysian premier polytechnics academics," Journal of Technical Education and Training, vol. 7, no. 2, pp. 1-11, 2015.

[29] N.A. Samad, et al., "Exploring domains and elements for behavioural competency and employability skills," Journal of Technical Education and Training, vol. 10, no. 1, pp. 82-90, 2018.

[30] S. Cheng, "A contextual concept of science,"Acta Baltica Historiae et Philosophiae Scientiarum, vol. 4, no. 2, pp. 53-68, 2016.

[31] R.A.Z. El Islami, et al., Development of guided inquiry learning model based on local wisdom of the baduy tribe society in increasing student science literacy (in Bahasa), Report of Research, Faculty of Teacher Training and Education, University of Sultan Ageng Tirtayasa, Indonesia, 2016a.

[32] J.R. Fraenkel, et al., How to design and evaluate research in education. New York: McGraw-Hill, 2012.

[33] V. Prachagool, et al., "Pedagogical decision making through the lens of teacher preparation program," Journal for the Education of Gifted Young Scientists, vol. 4, no. 1, pp. 41-52, 2016. 
[34] A. Saefullah, et al., "Efforts to improve scientific literacy of students through guided inquiry learning based on local wisdom of Baduy's society," Jurnal Penelitian dan Pembelajaran IPA, vol. 3, no. 2, pp. 84-91, 2017.

[35] R.A.Z. El Islami, et al., "Building student science literacy on the concept of acid bases through guided inquiry learning (in Bahasa)," Jurnal Penelitian dan Pembelajaran IPA, vol.2, no. 2, pp. 110-120, 2016.

[36] A. Rakhmawan, et al., "Design of science literacy-based learning inquiry in laboratory activities (in Bahasa)," Jurnal Penelitian dan Pembelajaran IPA, vol. 1, no. 1, pp. 143-152, 2015.

[37] F. Fakhriyah, et al., "Student's science literacy in the aspect of content science?" Jurnal Pendidikan IPA Indonesia, vol. 6, no. 1, pp. 81-87, 2017.

[38] N.N.L. Handayani, "Building a National Society of Science Literacy through Learning (in Bahasa)," in Prosiding Seminar Nasional Mipa, 2015.

[39] R. Zidny and I. Eilks, "Indigenous knowledge as a socio-cultural context of science to promote transformative education for sustainable development: Insights into a case study on The Baduy community (Indonesia)." In Eilks, I., Markic, S. and Ralle, B. (Eds.). Building bridges across disciplines for transformative education and a sustainable future. A Collection of Invited Papers Inspired by the 24th Symposium on Chemistry and Science Education Held at the University of Bremen, pp. 249-256, 2018.

[40] C. Yuenyong and P. Narjaikaew, "Scientific literacy and Thailand science education," International Journal of Environmental \& Science Education, vol. 4, no. 3, pp. 335-349, 2009.

[41] D. Sofiani, et al., "Gender differences in students' sttitude towards science," Journal of Physics: Conference Series, vol. $895,2017$.

[42] F. Neolaka, et al., "Implementation of 2013 Curriculum in Junior high schools 1 Kupang Tengah Kupang Regency in the Academic Year 2013/2014," Jurnal Pendidikan: Teori, Penelitian, dan Pengembangan, vol. 1, no. 10, pp. 2010-2015, 2016.

[43] B. Setiawan, et al., "The development of local wisdom-based natural science module to improve science literation of students," Jurnal Pendidikan IPA Indonesia, vol. 6, no. 1, pp. 49-54, 2017. 